\title{
Mineralisations in the Malene supracrustals in the Godthåb area, West Greenland
}

\author{
Peter W. Uitterdijk Appel
}

The geology of the Godthåb area, West Greenland, has been studied for several decades, mainly by the Geological Survey of Greenland (GGU), but also by groups from British and other Universities. This work has resulted in a detailed understanding of most of the major rock forming events which have affected the area. However, one important aspect of the geology has been largely neglected in the previous work, that is the metallogeny of the rock units in the area. Mining companies have undertaken only scattered work in the area, e.g. on the molybdenite mineralisation in Narssaq, south of Godthåb. It was therefore decided to launch a reconnaissance study of the mineralisations of one of the major rock units, the Malene supracrustals. Rather detailed work was carried out on Qilángarssuit, Sagdlerssua and Simiútat, while Narssaq, Angissúnguaq and Mitsimavissuaq were visited for a short period only.

\section{Regional geology}

In the Godthåb area two types of gneisses are found, the Amîtsoq gneisses and the Nûk gneisses, the former being the oldest with isotopic ages of 3700 m.y. (Black et al., 1971). In the Amitsoq gneisses enclaves of an older supracrustal belt occur, the Akilia enclaves. The most extensive and best known enclave is the $30 \mathrm{~km}$ long Isua supracrustal belt. The most important lithologies in the supracrustals are banded amphibolites, horizons of banded iron formation, together with small amounts of metasediments.

The younger Nûk gneisses were intruded some 3000 m.y. ago (Pankhurst et al., 1973). Within the Nûk gneisses a large number of supracrustal fragments occur; these are the Malene supracrustals. No age determinations have been made on the supracrustals, but field evidence shows that they are younger than $3700 \mathrm{~m} . \mathrm{y}$. and older than $3000 \mathrm{~m} . \mathrm{y}$. The Malene supracrustals consist of amphibolites, aluminium-rich metasediments and skarn horizons; they are found over a distance of several hundred kilometres from the inner Godthabsfjord to the Fiskenæsset area.

The youngest major event in the Godthåb area is the intrusion of the Qôrqut granite 2600 m.y. ago (Pankhurst et al.,1973).

\section{Mineralisations in the Malene supracrustals}

In the Godthåb area, Malene supracrustals are found along the coast south of Godthåb (fig. 20) and in the Godthåbsfjord and Ameralik areas. Much detailed work has previously been done on mapping selected areas e.g. Simiútat and Qilángarssuit (Beech \& Chadwick, 1980), but very little work was done on the occurrence of ore minerals. In fact the only recorded mineralisation is that on Simiútat (Beech \& Chadwick, 1980).

In the Malene supracrustal rocks several types of mineralisation occur, of which the most important are: 


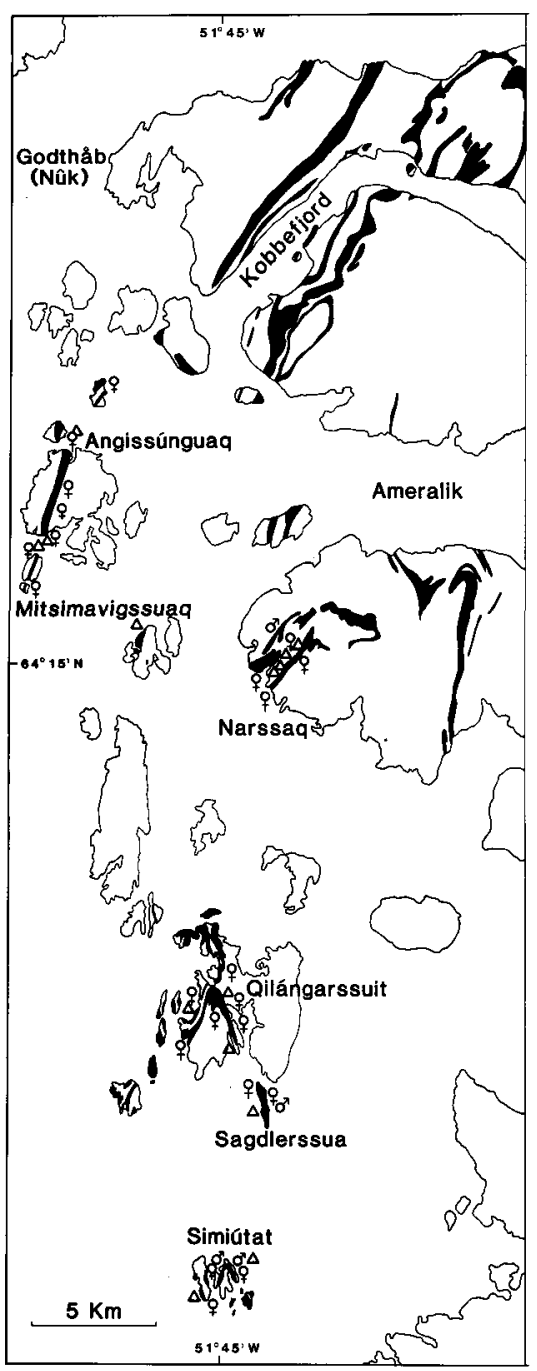

\section{LEGEND}

Malene Supracrustal rocks

$0^{x}$ Iron-formation

i Copper mineralisation

$\Delta$ Molybdenum mineralisation

Fig. 20. Geological sketch map of the area south of Godthåb showing the location of some of the mineralised areas in the Malene supracrustal rocks.

\section{Banded iron-formation}

2. Copper sulphide mineralisation

3. Molybdenum mineralisation

Horizons of banded iron-formation have been found on Simiútat, Sagdlerssua and Narssaq (fig. 20). On Storø in Godthåbsfjord (north-east of fig. 20) abundant loose blocks of iron-formation have been found in a scree below a very steep wall of Malene supracrustals. There is little doubt that the loose blocks on Storø are derived from Malene supracrustals, but they have not yet been found in situ.

The iron-formation on Simiútat found by Beech \& Chadwick (1980) was traced with intervals along strike for several hundred metres. It is a few metres wide, weakly banded 
with magnetite-rich layers alternating with layers of iron silicates. The magnetite and silicate bands are up to several tens of centimetres thick. In the iron silicate layers local accumulations of massive pyrite are found. Along cleavage planes and interstitial to the iron silicates scattered occurrences of native copper are seen. Another peculiar feature is the presence of disseminated molybdenite.

On Sagdlerssua (fig. 20) a minor horizon of quartz magnetite banded iron-formation occurs. It is only a few tens of centimetres wide and can be traced for only 2 to 3 metres. In the Narssaq area an outcrop about $2 \times 5 \mathrm{~m}$ of iron-formation in amphibolite was found. It is a banded magnetite iron silicate rock with small amounts of pyrrhotite and chalcopyrite. It was not possible to trace this horizon further along strike because it was covered with snow.

In the Ivisârtoq area in the inner part of Godthåbsfjord an extensive stratabound, partly massive, partly disseminated pyrite mineralisation is seen. It is up to $50 \mathrm{~m}$ thick and can be traced for more than $10 \mathrm{~km}$ along strike. This mineralisation can be regarded as a sulphide facies iron-formation.

Horizons of iron-formation do not appear to be common in the Malene supracrustals, but they do occur. This is important, since the presence of iron-formation in supracrustal enclaves has been used as an indicator of Akilia age.

\section{Copper sulphide mineralisation}

Copper mineralisation is quite abundant in the Malene supracrustals. The most common mode of occurrence is as disseminations or very thin layers of sulphides in weakly banded amphibolites, together with pyrrhotite. The amount of sulphides rarely exceeds 5 per cent, but higher grades with massive chalcopyrite and pyrrhotite are locally important, e.g. on western Qilángarssuit. During metamorphism and deformation some of the sulphides have been mobilised and are now found in thin discordant veins, often associated with small amounts of quartz.

One of the most interesting copper mineralisations is found on eastern Sagdlerssua, where up to 10 per cent chalcopyrite occurs in an aluminium-rich metasediment. The mineralized zone is a few metres wide and can be traced for some tens of metres; the continuation of the zone at both ends is not exposed. A peculiar feature in the Sagdlerssua mineralisation is that only traces of pyrrhotite are found together with the chalcopyrite.

\section{Molybdenum mineralisation}

Molybdenite is quite common in the Precambrian rocks of the Godthåb area where it occurs as scattered flakes in gneisses, amphibolites and even in anorthosites. The origin of these scattered grains of molybdenite has been problematical for a long time.

Molybdenite deposits are so far only known in the Malene supracrustal rocks. The first studies were made by V. R. McGregor in the Narssaq area where the molybdenite is confined to a sequence of green skarn rocks. This type of occurrence is widely distributed throughout the Malene supracrustals as seen in figure 20 . The mineralised horizons are up to several tens of metres wide and consist of metre-thick green skarn layers alternating with thin, black to grey amphibolites. Molybdenite is generally confined to the skarn layers, but is occasionally also found in the amphibolites. The only exception to the molybdenite skarn association is the disseminated molybdenite in the iron-formation on Simiutat. 


\section{Discussion}

Horizons of banded iron-formation are found at several localities in the Malene supracrustals. It was previously believed that only the older Akilia (Isua) supracrustal enclaves contained iron formation. It is now evident, that the presence of an iron-formation in a supracrustal enclave cannot be used to determine whether the enclave is of Akilia or Malene age.

Chalcopyrite appears to be quite common in the Malene supracrustals south of Godthåb. It is mostly associated with layered amphibolites, where the occurrence is disseminated or in very thin layers. During metamorphism chalcopyrite has been mobilised and is now found as massive chalcopyrite together with pyrrhotite.

Molybdenite is scattered throughout the Precambrian rocks in the region. Mineralisation is, however, only found in skarn layers within the Malene supracrustals.

The iron-formation and the copper sulphide mineralisation in the Malene supracrustal rocks are quite similar to those seen in other supracrustal belts. Almost identical horizons of iron-formation and copper mineralisation have been described from the Isua supracrustal belt, where they are ascribed to submarine volcanic exhalations (Appel, 1979, 1980). The main difference between the mineralisation in the Isua and Malene supracrustal rocks is that oxide-facies iron-formation is common in the Isua belt, but very rare in the Malene rocks, where a more reduced facies of iron-formation prevails. This accords well with the abundance of aluminium-rich metasediments in Malene rocks, which indicates a quite different depositional environment compared with the Isua belt where aluminium-rich metasediments are rare.

\section{References}

Appel, P. W. U. 1979: Stratabound sulfides in a banded iron-formation and in basaltic tuffs in the Early Precambrian Isua supracrustal belt, West Greenland. Econ. Geol. 74, 45-52.

Appel, P. W. U. 1980: On the Early Archaean Isua iron-formation, West Greenland. Precambrian Res. 11, 73-87.

Beech, E. M. \& Chadwick, B. 1980: The Malene supracrustal gneisses of northwest Buksefjorden: their origin and significance in the Archaean crustal evolution of southern West Greenland. Precambrian Res. 11, 329-355.

Black, L. P., Gale, N. H., Moorbath, S., Pankhurst, R. J. \& McGregor, V. R. 1971: Isotopic dating of very early Precambrian amphibolite facies gneisses from the Godthåb district, West Greenland. Earth planet. Sci. Lett. 12, 245-259.

Pankhurst, R. J., Moorbath, S., Rex, D. C. \& Turner, G. 1973: Mineral age patterns in ca 3700 m.y. old rocks from West Greenland. Earth planet. Sci. Lett. 20,157-170. 